\title{
Do Price Subsidies Lead to Over Application of Fertilizers? An Analysis of Kethata-Aruna Program of Sri Lanka
}

\author{
H. Kanthilanka ${ }^{1 *}$ and J. Weerahewa ${ }^{1}$ \\ Postgraduate Institute of Agriculture \\ University of Peradeniya \\ Sri Lanka
}

\begin{abstract}
Paddy sector has always been given special treatments by successive governments of Sri Lanka and among the treatments, provision of subsidized fertilizer to smallscale paddy farmers has been recorded as the most expensive program. It has been argued that provision of subsidies had led to the sub-optimum application of fertilizers. This study examined the pattern of chemical fertilizer application by the farmers and paddy yields during the period 2005-2015 where a price subsidy on fertilizer was implemented. During this period, the chemical fertilizer levels recommended by the Department of Agriculture were provided at a rate of Rs. 350 per $50 \mathrm{~kg}$ bag to the paddy farmers by the Agrarian Service Centres. A production function was estimated in quadratic form using data extracted from cost of cultivation reports of the Department of Agriculture to determine the effects of application of fertilizer on paddy yields. The results of econometric estimation revealed that the effect of urea application on yield was positive and statistically $(p<0.05)$ significant. A simulation exercise was performed to compare potential urea application levels under alternative fertilizer price levels for a profit maximizing farmer. The results indicated a potential over application of fertilizers beyond the recommended levels under the subsidized price levels. However, in practice, farmers could not purchase quantities that would have given them the maximum possible profit as only the recommended levels were provided under the subsidy scheme. The results further indicated that profit maximizing farmers may continue to use urea fertilizers even if the price subsidy is removed.
\end{abstract}

Keywords: Urea fertilizer, input subsidy, paddy farming, Sri Lanka

\section{INTRODUCTION}

Provision of incentives to apply more chemical fertilizers in Sri Lanka was initiated in 1962 with the introduction of High Yielding Variety (HYV). The HYVs are highly responsive for fertilizers and hence it was essential to apply inorganic fertilizers to achieve expected yields. The overall aims of providing a subsidy on fertilizers were to enhance the land productivity and to reduce the cost of production of paddy farming, thereby to increase the profitability of paddy farming (Weerahewa et al., 2010).

The subsidy program for fertilizers prevailed from 2005 to 2015 was named as Kethata Aruna program. It was initially targeted small paddy farmers who cultivated less than five acres of

\footnotetext{
1 Department of Agricultural Economics and Business Management, Faculty of Agriculture, University of Peradeniya, Sri Lanka and Faculty of Veterinary and Agricultural Sciences, University of Melbourne, Australia

* Corresponding author: kanthilanka.hema@gmail.com
} 
land. The farmers were provided with the recommended quantities of Urea, Triple Super Phosphate (TSP) and Muriate of Potash (MOP) by the Department of Agriculture (DoA) at the rate of Rs.350.00 per $50 \mathrm{~kg}$ through the Department of Agrarian Service Centers. In 2006, tea, coconut and rubber smallholders (with less than five acres of holding size) also became eligible for the subsidy. The program was expanded to cover all other crops in 2011 and fertilizers were provided at a rate of Rs. $1,200.00$ per $50 \mathrm{~kg}$ bag for all other crops. According to the Ministry of Finance and Planning, approximately $91.5 \%$ of the total cost of fertilizers subsidized during the program. Even though, the targeted benefits through the Kethta Aruna program were to increase rice productivity, to reduce the cost of food imports, to reduce farmers' cost of production and to channel the benefits to consumers (MADAS, 2007). Mixed effects of the program on the paddy economy have been observed. Some claim that the program led to over application of fertilizers which led to pollution of water bodies and some health issues of the country (Wimalawansa, 2014).

A few studies addressed the effects of fertilizer subsidy scheme on fertilizer application rates and paddy yields. Wickramasinghe et al. (2009) found that this fertilizer subsidy changed the fertilizer application patterns and increased paddy yields within Sri Lanka. Semsinghe (2014) found that the fertilizers subsidy scheme increased private benefits of paddy cultivation due to reductions in the cost of fertilizers application at farm level. Ekanayake (2009) indicated that fertilizer application rate is mainly determined by the paddy price and the effect of fertilizer price is rather small.

Production function is an appropriate model to determine the nature of the technical relationship between fertilizer and paddy yields though it has not been widely used by the previous authors to address issues with respect to fertilizer subsidy program in Sri Lanka. This approach however has been used to address various other issues in paddy cultivation. Abeysekara (1980) revealed that paddy production in Maha season was highly responsive to the application of fertilizers and the availability of labour and it was negatively affected by other agro-chemicals application. Furthermore, coefficient estimates revealed that paddy production technology was characterized by increasing returns to scale. Karunaratne and Herath (1989) found that there are significant differences in yield between Maha season and Yala season. Yala season cultivation was significantly affected by land, fertilizer application, agrochemicals and family labour while the extent of land and fertilizers use affect paddy production in Maha season. In both seasons hired labour did not have a significant effect on production. Udayanganie et al. (2006) revealed that the extent of cultivation, fertilizers usage and pesticide usage significantly influenced paddy production during the 2003/04 Maha season. This paper examines the optimal application rates of fertilizer for a profit-maximizing paddy farmer using coefficients of an econometrically estimated production function.

\section{METHODOLOGY}

\section{Specification and estimation of the production function}

Among different types of production function specifications, the quadratic form was selected for the estimation in this study as it allows identification of a local maximum or a minimum. With a local maximum, the corresponding marginal product declines as input usage increases, then becomes zero when the output is at its maximum and takes negative values thereafter. The specification adopted is given below (Equation 1) and the description of variables are presented in Table 1. 


$$
\begin{aligned}
& \text { Yiled } \left.=\alpha+\beta_{1}(\text { Season })+\beta_{2}(\text { Irrgation })+\beta_{3} \text { (Trend }\right)+\beta_{4}(\text { Machinery })+ \\
& \beta_{5}(\text { Seed })+\beta_{6}(\text { Urea })+\beta_{7}(\text { TSP })+\beta_{8}(\text { MOP })+\beta_{9}(\text { Labour })+ \\
& \left.\beta_{10} \text { (Machinery } * \text { Machinery }\right)+\beta_{11}(\text { Seed } * \text { Seed })+ \\
& \beta_{12}(\text { Urea } * \text { Urea })+\beta_{13}(\text { TSP } * \text { TSP })+\beta_{14}(M O P * M O P)+ \\
& \beta_{15}(\text { Labour } * \text { Labour })
\end{aligned}
$$

\begin{tabular}{|c|c|c|c|}
\hline Category & $\begin{array}{l}\text { Variable } \\
\text { name }\end{array}$ & Description & Units \\
\hline $\begin{array}{l}\text { Dependent } \\
\text { Variable }\end{array}$ & Yield & Average Yield & $\mathrm{kg} / \mathrm{acre}$ \\
\hline \multirow[t]{9}{*}{$\begin{array}{l}\text { Independent } \\
\text { Variables }\end{array}$} & Trend & Year & $\begin{array}{l}1 \text { for } 2005 \ldots 11 \text { for } \\
2015\end{array}$ \\
\hline & Irrigation & Irrigation regime & $\begin{array}{l}\text { Dummy } \\
D=0 \text {, Rain-fed } \\
D=1 \text {, Irrigated }\end{array}$ \\
\hline & Season & Cultivating season & $\begin{array}{l}\text { Dummy } \\
\mathrm{D}=0, \text { Maha season } \\
\mathrm{D}=1, \text { Yala } \text { season }\end{array}$ \\
\hline & Machinery & $\begin{array}{l}\text { Total machinery cost per season in } \\
\text { real monetary value (base year 2002) }\end{array}$ & Rs. /acre \\
\hline & Seed & Seed paddy used per season & $\mathrm{kg} / \mathrm{acre}$ \\
\hline & Urea & Total Urea application per season & $\mathrm{kg} / \mathrm{acre}$ \\
\hline & TSP & Total TSP application per season & $\mathrm{kg} / \mathrm{acre}$ \\
\hline & MOP & Total MOP application per season & $\mathrm{kg} / \mathrm{acre}$ \\
\hline & Labour & Hired and Family labor per season & Man-days/acre \\
\hline
\end{tabular}

where, $\alpha$ and $\beta$ are parameter esetimates.

Table 1. Description of variables in the production function

\section{Optimum level of fertilizer application:}

The optimum level of Urea application is defined as the application level where the Marginal Value Product (MVP) of Urea is equal to the Marginal Factor Cost of Urea which is the price of Urea.

Marginal product of Urea is given by:

$$
M P P_{\text {Urea }}=\beta_{6}+2\left(\beta_{12} * \text { Urea }\right)
$$

where,

$M P P_{\text {Urea }}=$ Margina Physical Product of Urea

$\beta_{6} \quad=$ Coefficient of Urea in the Production Function

$\beta_{12}=$ Coefficinet of the Interaction Term of Urea in Production Function

Marginal value product of Urea is given by:

$$
\begin{aligned}
& M V P_{\text {Urea }}=M P P_{\text {Urea }} * P_{\text {Paddy }} \\
& \quad M V P_{\text {Urea }}=\left\{\beta_{6}+2\left(\beta_{12} * \text { Urea }\right)\right\} * P_{\text {Paddy }}
\end{aligned}
$$

where,

$M V P_{\text {Urea }}=$ Marginal Value Product of Urea and $P_{\text {Paddy }}=$ Output Price of Paddy. 
Optimality condition is given by:

$$
\begin{aligned}
M V P_{\text {Urea }} & =P_{\text {Urea }} \\
\left\{\beta_{6}+2\left(\beta_{12} * \text { Urea }\right)\right\} * P_{\text {Paddy }} & =P_{\text {Urea }}
\end{aligned}
$$

Optimum level of Urea is given by:

$$
\text { Urea }=\frac{P_{\text {Urea }}}{2\left(P_{\text {Padd }} \beta_{12}\right)}-\frac{\beta_{6}}{2 \beta_{12}}
$$

Price of Urea $\left(P_{\text {Urea }}\right)$ depends on the scenario under consideration. With the fertilizers subsidy scheme, price of Urea is subsidized price. If fertilizers subsidy is completely removed, then the price of Urea is the market price of Urea. At maximum yield level price of Urea should be zero, according to production theory. The price of Urea that gives rise to a particular Urea application is given by:

\section{Sources of data}

$$
P_{\text {Urea }}=\left\{\beta_{6}+2\left(\beta_{12} * \text { Urea }\right)\right\} * P_{\text {Paddy }}
$$

Secondary data gathered from Cost of Cultivation reports of the Department of Agriculture, Sri Lanka published during 20015-2015 was used. Data on seed paddy, labor, machinery, fertilizers and paddy production at district level data for main cropping seasons (Yala season and Maha season) at different irrigation management (rainfed and irrigated) were employed. The main type of fertilizers considered were Urea, MOP and TSP while the fertilizers recommendation (2001 and 2013) for paddy by the Department of Agriculture was fixed as crop requirement of fertilizer. Fertilizers' price data were obtained from the annual reports of the Ministry of Finance and Planning. The farming locations covered were Ampara, Anuradhapura, Hambantota, Kurunegala, Mannar, Polonnaruwa, Mahaweli (B, C, H), Trincomalee, Gampaha, Kalurata and Kandy. Altogether 234 observations were used in the study for different years with uneven distribution over the years.

\section{RESULTS AND DISCUSSION}

\section{Descriptive statistics}

Table 2 presents the descriptive statistics of the data used for the estimation. Inputs include seed paddy, machinery, labour and fertilizers application. Urea, TSP and MOP were the types of fertilizer considered for the study. Both family labour and hired labour were included in variable "labour". Cost of machinery use was included as a monetary value.

Table 2. Descriptive statistics of the variable.

\begin{tabular}{llllll}
\hline Variable Name & Units & Mean & SD & Minimum & Maximum \\
\hline Yield & kg/acre & $1,897.14$ & 431.82 & 706.00 & $2,826.00$ \\
Machinery & Rs. /acre & $5,097.61$ & $1,166.49$ & 809.80 & $7,885.35$ \\
Seed & kg/acre & 49.81 & 12.93 & 36.23 & 99.30 \\
Urea & kg/acre & 92.48 & 23.11 & 36.00 & 146.00 \\
TSP & kg/acre & 31.86 & 7.20 & 13.00 & 59.00 \\
MOP & kg/acre & 32.72 & 32.72 & 15.00 & 60.00 \\
Labour & Man-days/acre & 25.02 & 7.56 & 13.00 & 48.00 \\
\hline
\end{tabular}




\section{Results of the estimation of production function}

The results of the estimation are presented in Table 3. The goodness of fit of the quadratic functional form was $77.48 \%$. The estimates indicate that irrigated cultivation systems are more productive than rain-fed and the yield differences between the two seasons are statistically significant. Among conventional input used for paddy cultivation, machinery, labour and Urea application significantly affect the paddy yields. Machinery usage negatively affects while application of Urea positively affects the productivity of paddy.

Table 3. Results of estimation of paddy production function in Sri Lanka 2005-2015.

\begin{tabular}{lllll}
\hline Variable & Coefficient value & S.E. & t value & P value \\
\hline Season & $53.17^{*}$ & 28.03 & 1.90 & 0.059 \\
Irrigation & $548.12^{* *}$ & 54.44 & 10.07 & 0.000 \\
Trend & $17.55^{*}$ & 9.03 & 1.94 & 0.053 \\
Machinery & $-0.22^{* *}$ & 0.08 & -2.55 & 0.011 \\
Seed & 8.01 & 11.41 & 0.70 & 0.480 \\
Urea & $10.61 *$ & 4.69 & 2.26 & 0.024 \\
TSP & -4.79 & 16.52 & -0.29 & 0.772 \\
MOP & 20.74 & 15.12 & 1.37 & 0.172 \\
Labour & $27.29 *$ & 14.03 & 1.94 & 0.053 \\
Machinery* Machinery & $2.49 \times 10^{-5 * *}$ & $8.28 \times 10^{-6}$ & 3.00 & 0.003 \\
Seed*seed & 0.01 & 0.09 & 0.09 & 0.927 \\
Urea*Urea & -0.04 & 0.03 & -1.42 & 0.158 \\
TSP*TSP & -0.02 & 0.24 & -0.08 & 0.937 \\
MOP*MOP & -0.28 & 0.21 & -1.37 & 0.172 \\
Labour*Labour & $-0.46^{*}$ & 0.24 & -1.94 & 0.053 \\
Constant & 205.07 & 533.39 & 0.38 & 0.701 \\
\hline
\end{tabular}

** significant at 5\% level * significant at $10 \%$ Source: Authors' estimations

\section{Optimum level fertilizer application in paddy production}

Among the three fertilizers, only Urea has a statistically significant effect on the paddy yield and hence optimum levels of Urea under various scenarios were simulated in this study. The following section summarizes the results obtained from the pooled sample.

It is important to note that the average application of Urea in the pooled sample was $92.48 \mathrm{~kg} / \mathrm{acre}$ and it corresponds to $1,898.40 \mathrm{~kg} / \mathrm{acre}$ of paddy production. The DOA recommendation of Urea application for the pooled sample is $87.42 \mathrm{~kg} /$ acre indicating a slight over-application of Urea by farmers compared to the recommendation. The simulation results indicated that profit-maximizing paddy farmers would maintain the recommended level of application of Urea when Urea is sold at Rs.122.00 per kg at the market. The recommended rate of application will be resulted about $1,844.68 \mathrm{~kg} / \mathrm{acre}$ of paddy. Table 4 shows the key findings of the simulation exercise.

The results of the production function estimates revealed that the maximum potential yield of $2,476.03 \mathrm{~kg} /$ acre of paddy will be achieved when $146.90 \mathrm{~kg} / \mathrm{acre}$ of Urea is applied. It was found that if an unlimited quantity of Urea fertilizer is sold at Rs. 7.00 per $\mathrm{kg}$, farmers would apply $143.20 \mathrm{~kg} / \mathrm{acre}$ of Urea and obtain a paddy yield of $2,436.61 \mathrm{~kg} / \mathrm{acre}$. This implies that if subsidized Urea is provided without any limits on the quantity, the application corresponds 
to the application associated with maximum yield. If the government does not intervene to fertilizer market, Urea would be sold at Rs. 60.78 per kilogram. The simulation results revealed that optimal application of Urea at this price would be $116.61 \mathrm{~kg} / \mathrm{acre}$ which will give rise to a yield of $2,154.42 \mathrm{~kg} / \mathrm{acre}$.

These results indicate that the actual application is far below the simulated application levels. This under-application is partly due to the quota level associated with the distribution of fertilizers, i.e., subsidized fertilizers were given only up to the recommended rates. It is also since farmers might not be maximizing profits as anticipated.

Table 4. Optimum level of Urea under different conditions: Pooled sample.

\begin{tabular}{llll}
\hline Scenario & $\begin{array}{l}\text { Level of Urea } \\
\text { (kg/acre) }\end{array}$ & $\begin{array}{l}\text { Price of } \\
\text { Urea } \\
\text { (Rs. /kg) }\end{array}$ & $\begin{array}{l}\text { Paddy } \\
\text { yield } \\
\text { (kg/acre) }\end{array}$ \\
\hline DOA recommendation of application & 87.42 & 122.00 & $1,844.68$ \\
Maximum yield level & 146.90 & & $2,476.03$ \\
Urea is sold with subsidy: No quota on sales & 143.20 & 7.00 & $2,436.61$ \\
Urea is sold at market prices & 116.61 & 60.78 & $2,154.42$ \\
Actual fertilizer application by farmers & 92.48 & & $1,898.40$ \\
\hline
\end{tabular}

The above results mask the variability within and across geographical locations, seasons and years. The following sections provide optimum levels of Urea for main paddy producing areas for Yala season and Maha season. Ampara, Anuradhapura, Hambanthota, Polonnaruwa and Kurunegala were selected as dry zone districts and Gampaha, Kandy and Kaluthra were chosen as the wet zone for the analysis. The year 2014 was used as the reference year.

Tables 5 and 6 present the key results for dry zone districts. The application of Urea in Ampara and Kurunegala (irrigated) slightly deviated from the recommended level. In Maha season actual yields in different locations were varied between $2,062.70 \mathrm{~kg} / \mathrm{acre}$ to $2,346.00 \mathrm{~kg} / \mathrm{acre}$. Even though profit-maximizing paddy farmer is expected to apply $144.00 \mathrm{~kg} / \mathrm{acre}$ of Urea, the actual application was around $50 \mathrm{~kg} /$ acre less than this amount. Under free market price, the Urea application level for a profit-maximizing farmer range from $122.00 \mathrm{~kg} / \mathrm{acre}$ to $128.00 \mathrm{~kg} / \mathrm{acre}$ and if farmers in dry zone aim maximize yield $147.00 \mathrm{~kg} / \mathrm{ha}$ of Urea should be applied. The level is far more of the DOA recommendation level of Urea. 
Table 5. Expected yield level, Urea level and price of Urea under different policy perspectives for Maha season in dry zone areas

\begin{tabular}{|c|c|c|c|c|c|c|}
\hline Variable & Location & $\mathbf{W S}^{2}$ & WOS & DOAR & MY & $\mathbf{A F A} \mathbf{A}^{3}$ \\
\hline \multirow{7}{*}{$\begin{array}{l}\text { Paddy } \\
\text { yield } \\
\text { (kg/acre) }\end{array}$} & Ampara East & $2,802.13$ & $2,599.63$ & $2,224.00$ & $2,828.03$ & $2,234.61$ \\
\hline & Ampara West & $2,750.40$ & $2,563.44$ & $2,170.28$ & $2,774.32$ & $2,117.22$ \\
\hline & Anuradhapura & $2,787.73$ & $2,576.67$ & $2,210.69$ & $2,814.73$ & $2,210.69$ \\
\hline & Hambanthota & $2,927.30$ & $2,744.59$ & $2,346.64$ & $2,950.67$ & $2,346.64$ \\
\hline & Kurunegala $(R F)$ & $2,635.84$ & $2,398.86$ & $2,062.70$ & $2,666.74$ & $2,062.70$ \\
\hline & Kurunegala (IR) & $2,621.11$ & $2,410.22$ & $2,044.05$ & $2,648.09$ & $2,097.12$ \\
\hline & Pollonnaruwa & $2,660.01$ & $2,434.60$ & $2,085.36$ & $2,689.40$ & $2,085.36$ \\
\hline \multirow{7}{*}{$\begin{array}{l}\text { Price of } \\
\text { Urea } \\
\text { (Rs. /kg) }\end{array}$} & Ampara East & 7.00 & 61.72 & 163.22 & & \\
\hline & Ampara West & 7.00 & 61.72 & 176.79 & & \\
\hline & Anuradhapura & 7.00 & 61.72 & 156.61 & & \\
\hline & Hambanthota & 7.00 & 61.72 & 180.9 & & \\
\hline & Kurunegala (RF) & 7.00 & 60.70 & 136.87 & & \\
\hline & Kurunegala (IR) & 7.00 & 61.72 & 156.73 & & \\
\hline & Polonnaruwa & 7.00 & 60.70 & 143.90 & & \\
\hline \multirow{7}{*}{$\begin{array}{l}\text { Level of } \\
\text { Urea } \\
\text { (kg/acre) }\end{array}$} & Ampara East & 144.47 & 125.39 & 90.00 & 146.91 & 91.00 \\
\hline & Ampara West & 144.66 & 127.05 & 90.00 & 146.91 & 85.00 \\
\hline & Anuradhapura & 144.37 & 124.48 & 90.00 & 146.91 & 90.00 \\
\hline & Hambanthota & 144.71 & 127.5 & 90.00 & 146.91 & 90.00 \\
\hline & Kurunegala $(R F)$ & 144.00 & 121.67 & 90.00 & 146.91 & 90.00 \\
\hline & Kurunegala (IR) & 144.37 & 124.50 & 90.00 & 146.91 & 95.00 \\
\hline & Polonnaruwa & 144.15 & 122.91 & 90.00 & 146.91 & 90.00 \\
\hline
\end{tabular}

Note: WS: With Fertilizer Subsidy, WOS: Without Fertilizer Subsidy, DOAR: Department of Agriculture Fertilizer Recommendation, MY: Maximum Yield Level, AFA: Actual fertilizer Application by Farmers, RF: Rainfed, IR: Irrigated

\footnotetext{
${ }^{2}$ WS indicate the simulations with subsidy and without quota of fertilizer.

${ }^{3}$ AFA indicate the actual fertilizer application and paddy yield obtained by paddy farmers with subsidy under quota of fertilizer issues.
} 
Table 6. Expected yield level, Urea level and price of Urea under different policy perspectives for Yala season in dry zone areas

\begin{tabular}{lllllll}
\hline Variable & Location & WS & WOS & DOAR & MY & AFA \\
\hline & Ampara East & $2,784.52$ & $2,527.37$ & $2,214.01$ & $2,818.04$ & $2,192.78$ \\
& Ampara West & $2,603.73$ & $2,369.63$ & $2,030.21$ & $2,634.25$ & $2,030.21$ \\
Paddy & Anuradhapura & $2,679.90$ & $2,430.79$ & $2,108.34$ & $2,712.37$ & $2,044.66$ \\
yield & Hambanthota & $2,856.33$ & $2,601.83$ & $2,285.47$ & $2,889.5$ & $2,285.47$ \\
(kg/acre) & Kurunegala $(R F)$ & $2,080.42$ & $1,829.88$ & $1,296.78$ & $2,113.07$ & $1,286.17$ \\
& Kurunegala $(I R)$ & $2,198.81$ & $1,971.71$ & $1,411.56$ & $2,227.86$ & $1,369.11$ \\
& Polonnaruwa & $2,705.28$ & $2,496.03$ & $2,128.01$ & $2,732.05$ & $2,011.27$ \\
\hline & Ampara East & 7.00 & 60.70 & 126.14 & & \\
Price of & Ampara West & 7.00 & 60.70 & 138.56 & & \\
Urea & Anuradhapura & 7.00 & 60.70 & 130.21 & & \\
(Rs./ kg) & Hambanthota & 7.00 & 60.70 & 127.46 & & \\
& Kurunegala $(R F)$ & 7.00 & 60.70 & 174.97 & & \\
& Kurunegala $(I R)$ & 7.00 & 61.72 & 196.69 & & \\
& Polonnaruwa & 7.00 & 61.72 & 157.96 & & \\
Level of & Ampara East & 143.76 & 119.53 & 90.00 & 146.91 & 88.00 \\
Urea & Ampara West & 144.04 & 121.98 & 90.00 & 146.91 & 90.00 \\
(kg/acre) & Anuradhapura & 143.86 & 120.38 & 90.00 & 146.91 & 84.00 \\
& Hambanthota & 143.79 & 119.81 & 90.00 & 146.91 & 90.00 \\
& Kurunegala $(R F)$ & 143.84 & 120.23 & 70.00 & 146.91 & 69.00 \\
& Kurunegala $(I R)$ & 144.18 & 122.78 & 70.00 & 146.91 & 66.00 \\
& Polonnaruwa & 144.39 & 124.68 & 90.00 & 146.91 & 79.00
\end{tabular}

Note: WS: With Fertilizer Subsidy, WOS: Without Fertilizer Subsidy, DOAR: Department of Agriculture Fertilizer Recommendation, MY: Maximum Yield Level, AFA: Actual fertilizer Application by Farmers, RF: Rainfed, IR: Irrigated

As depicted in Tables 7 and 8, recommended levels of Urea are lesser for the wet zone compared to those for the dry zone. With the subsidy Urea application rate is more uniform across the locations in wet zone. If subsidy is eliminated, Urea would be sold around 60.00 Rs. $/ \mathrm{kg}$ and profit-maximizing paddy farmers in the wet zone would apply $118.00-125.00 \mathrm{~kg} / \mathrm{acre}$ of Urea.

Table 7. Expected yield level, Urea level and price of Urea under different policy perspectives for Maha season in wet zone areas

\begin{tabular}{lllllll}
\hline Variable & Location & WS & WOS & DOAR & MY & AFA \\
\hline \multirow{2}{*}{ Paddy yield } & Gampaha & $2,274.56$ & $2,034.25$ & $1,171.21$ & $2,305.89$ & $1,277.34$ \\
(kg/acre) & Kaluthara & $2,343.35$ & $2,080.37$ & $1,242.94$ & $2,377.63$ & $1,242.94$ \\
& Kandy & $2,352.12$ & $2,089.15$ & $1,251.72$ & $2,386.40$ & $1,251.72$ \\
\hline \multirow{2}{*}{ Price of Urea } & Gampaha & 7.00 & 60.70 & 253.56 & & \\
(Rs./ kg) & Kaluthara & 7.00 & 60.70 & 231.7 & & \\
& Kandy & 7.00 & 60.70 & 231.7 & & \\
Level of Urea & Gampaha & 143.96 & 121.32 & 40.00 & 146.91 & 50.00 \\
(kg/acre) & Kaluthara & 143.68 & 118.91 & 40.00 & 146.91 & 40.00 \\
& Kandy & 143.68 & 118.91 & 40.00 & 146.91 & 40.00 \\
\hline
\end{tabular}

Note: WS: With Fertilizer Subsidy, WOS: Without Fertilizer Subsidy, DOAR: Department of Agriculture Fertilizer Recommendation, MY: Maximum Yield Level, AFA: Actual fertilizer Application by Farmers, 
Table 8. Expected yield level, Urea level and price of Urea under different policy perspectives for Yala season in wet zone areas

\begin{tabular}{lllllll}
\hline Variable & Location & WS & WOS & DOAR & MY & AFA \\
\hline \multirow{2}{*}{ Paddy yield } & Gampaha & $2,310.20$ & $2,062.84$ & $1,207.16$ & $2,341.85$ & $1,313.29$ \\
(kg/acre) & Kaluthara & $2,621.11$ & $2,410.22$ & $2,044.05$ & $2,648.09$ & $2,097.12$ \\
& Kandy & $2,377.85$ & $2,109.88$ & $1,277.45$ & $2,412.13$ & $1,457.87$ \\
\hline \multirow{2}{*}{ Price of Urea } & Gampaha & 7.00 & 61.72 & 251.01 & & \\
(Rs./ kg) & Kaluthara & 7.00 & 61.72 & 156.73 & & \\
& Kandy & 7.00 & 61.72 & 231.70 & & \\
Level of Urea & Gampaha & 143.93 & 120.63 & 40.00 & 146.91 & 50.00 \\
(kg/acre) & Kaluthara & 144.37 & 124.50 & 90.00 & 146.91 & 95.00 \\
& Kandy & 143.68 & 118.44 & 40.00 & 146.91 & 57.00 \\
\hline
\end{tabular}

Note: WS: With Fertilizer Subsidy, WOS: Without Fertilizer Subsidy, DOAR: Department of Agriculture Fertilizer Recommendation, MY: Maximum Yield Level, AFA: Actual fertilizer Application by Farmers,

\section{CONCLUSIONS}

Since the price subsidy for fertilizers prevailed in Sri Lanka was associated with a quota system, farmers could not purchase quantities of urea fertilizer that would have given them the maximum possible profits. The results further indicate that profit-maximizing paddy farmers may continue to use Urea fertilizers even if the price subsidy is removed and with the removal of the quota associated with the price subsidy.

\section{REFERENCES}

Abeysekera, W. A. T. (1980). Production Efficiency in Paddy Farming. Sri Lankan Journal of Agricultural Sciences.1,12-14.

Ekanayake, H. (2009). The impact of fertilizer subsidy on paddy cultivation in Sri Lanka. Staff Studies. 3, 74-96.

Karunaratne, M.A.K.H.S.S and Herath, H.M.G, (1989). Efficiency of Rice Production Under Major Irrigation Conditions: A Frontier Production Function Approach, Tropical Agricultural Research. 1,142-158.

MADAS. (2007). National Agriculture Policy of Sri Lanka. Ministry of Agriculture Development and Agrarian Services, Colombo.

Ministry of Finance and Planning. (2008). Annual Report. Ministry of Finance and Planning, Colombo.

Ministry of Finance and Planning. (2009). Annual Report. Ministry of Finance and Planning, Colombo

Semasinghe, W. M. (2014). Economic and social cost of fertilizer subsidy on paddy farming in Sri Lanka. International Journal of Science and Research. 3,1261-1267. 
Udayanganie, A.D.D., Prasada, D.V.P., Kodithuwakku, K.A.S.S.,Weerahewa, . J. and Little, D.C. (2006). Efficiency of the Agrochemical Input Usage in the paddy Farming Systems in the Dry Zone of Sri Lanka. Annual Meeting of the Canadian Agricultural Economics Society in Montreal, Quebec, May 25th-28th, 2006.

Weerahewa, J., Kodithuwakku, S. S. and Ariyawardana, A. (2010). The fertilizer subsidy program in Sri Lanka. Food policy for developing countries: Case studies, ed. P. PinstrupAndersen and F. Cheng. Ithaca: Cornell University. Retrieved August, 26, 2014.

Wickramasinghe, W., Samarasinha, G. and Epasinghe, S. (2009). Fertilizer policy on paddy farming: Evaluation of subsidy program 2005. Hector Kobbekaduwa Agrarian Research and Training Institute, Colombo.

Wimalawansa, S. J. (2014). Escalating chronic kidney diseases of multi-factorial origin in Sri Lanka: causes, solutions, and recommendations. Environmental Health and Preventive Medicine. 19, 375-394. 